\title{
Antitrichomonal and antioxidant activities of Dorstenia barteri and Dorstenia convexa
}

N.O.A. Omisore ${ }^{1}$, C.O. Adewunmi ${ }^{1}$, E.O. Iwalewa ${ }^{1}$, B.T. Ngadjui ${ }^{3}$, T.K. Adenowo ${ }^{2}$, B.M. Abegaz ${ }^{4}$, J.A. Ojewole ${ }^{5}$ and J. Watchueng ${ }^{3}$

\author{
1Drug Research and Production Unit and Department of Pharmacology, \\ Faculty of Pharmacy, and ${ }^{2}$ Faculty of Basic Medical Sciences, \\ Obafemi Awolowo University, Ile-Ife, Nigeria \\ ${ }^{3}$ Department of Organic Chemistry, University of Yaoundé, Yaoundé, Cameroon \\ ${ }^{4}$ Department of Chemistry, University of Botswana, Gaborone, Botswana \\ ${ }^{5}$ Department of Pharmacology, University of Durban-Westville, South Africa
}

\section{Correspondence \\ C.O. Adewunmi \\ Drug Research and Production Unit \\ Faculty of Pharmacy \\ Obafemi Awolowo University \\ lle-lfe \\ Nigeria, 220005 \\ E-mail: cadewumi@yahoo.com}

Received March 22, 2004

Accepted February 4, 2005

\begin{abstract}
Dorstenia barteri and D. convexa extracts and some isolated components of the former were investigated for effectiveness against Trichomonas gallinarum and compared with quercetin and quercitrin. The antioxidant activity of the extracts/compounds was also determined. The minimum lethal concentrations (MLCs) for the extract of D. barteri leaves and twigs at $24 \mathrm{~h}$ were found to be 15.625 and 15.625 $\mu \mathrm{g} / \mathrm{ml}$, respectively. However, the MLCs of the leaf and twig extract of D. convexa were 125 and $437.5 \mu \mathrm{g} / \mathrm{ml}$, respectively. The prenylated and geranylated chalcones were as active as the prenylated flavones, 6prenylapigenin and the diprenylated derivative 6,8-diprenyleridictyol. The order of the antitrichomonal activity of the compounds at $24 \mathrm{~h}$ was: quercetin $(0.121 \mu \mathrm{g} / \mathrm{ml})>$ quercitrin $(0.244 \mu \mathrm{g} / \mathrm{ml}) \geq$ bartericin B $(0.244 \mu \mathrm{g} / \mathrm{ml})>$ bartericin A $(0.73 \mu \mathrm{g} / \mathrm{ml})>$ stigmasterol $(0.98 \mu \mathrm{g} / \mathrm{ml})$ $>$ 6,8-diprenyleridictyol $=$ isobavachalcone $=$ dorsmanin $\mathrm{F}(31.25 \mu \mathrm{g} /$ $\mathrm{ml})$. D. barteri extracts, quercitrin, and bartericin A, and the prenylated flavonoids had potent antioxidant properties. The twig extract of $D$. barteri was more potent than the leaf extract. Moderate $\left(\mathrm{EC}_{50}>50 \mu \mathrm{g} /\right.$ $\mathrm{ml})$ and high $\left(\mathrm{EC}_{50}<50 \mu \mathrm{g} / \mathrm{ml}\right)$ antioxidant activities were detected in the leaf and twig extracts of $D$. barteri and the prenylated flavonoids. Prenylated flavonoids and the isolated compounds with antioxidant properties described here may account for the anti-inflammatory action of these extracts. The antitrichomonal and antioxidant activities shown by the extracts and compounds in this study are consistent with the ethnomedicinal and local use of the Dorstenia species studied.
\end{abstract}

\section{Introduction}

There are about 170 species of the genus Dorstenia (Moraceae) worldwide (1). Decoctions of the leaves of some of these species are used for cough, headache and stom-
Key words

- Dorstenia species

- Antitrichomonal

- Antioxidant activity

- Prenylated flavonoids ach pain (2). Other uses include gout and various skin diseases (3).

Trichomoniasis affects men and animals causing untold economic loses in poultry and livestock and sometimes high morbidity in man. The prevalence of trichomoniasis is 
significantly higher in communities with high HIV prevalence (29.3\% in Kisumu and 34.3\% in Ndola) than in Cotonou (3.2\%) and Yaoundé (17.6\%) (4). In Nigeria, prevalence ranges from 6 to $46 \%$ depending on the age, profession and location of the subjects (5-9). Trichomonas gallinarum affects birds including poultry, causing high morbidity and mortality especially in young birds. There is no information available in the literature concerning the antitrichomonas activity of Dorstenia species. Antioxidant polyphenols are common in plants (10). Many defense mechanisms within the organism have evolved to limit the levels of reactive oxidants and the damage they inflict (11). It is estimated that $5 \%$ of all $T$. vaginalis patients' isolates display some level of resistance to metronidazole (12). In addition, patients also have adverse reactions to high doses of metronidazole or are allergic to this agent (13). Therefore, the search for a new antitrichomonal agent is certainly justified. The present study was carried out to examine and identify an agent from the array of compounds and extracts of Dorstenia species that possess antitrichomonal and antioxidant activities, to complement the use of this plant in the treatment and/or management of human disorders including arthritis, rheumatism, gout, stomach disorders, cough, headache, and skin diseases (1-3).

\section{Material and Methods}

\section{Plants and compounds}

Plant samples were collected from the Central Province of Cameroon. Specimens of the plants are deposited at the National Herbarium, Yaounde, Cameroon. Combined $\mathrm{CH}_{2} \mathrm{Cl}_{2} / \mathrm{MeOH}$ (1:1) extracts of Dorstenia convexa and $D$. barteri were obtained as previously described (14). The extraction and isolation of bartericins $\mathrm{A}$, and $\mathrm{B}$, stigmasterol, isobavachalcone, and 4-hydroxylonchocarpin have been previously described by Ngameni et al. (14). Four hundred and fifty grams of the twigs and $210 \mathrm{~g}$ of the leaves were extracted with a mixture of methylene chloride and methanol (1:1) for $24 \mathrm{~h}$. Dorsmanin F and 6,8-diprenyleridictyol (Table 2) were isolated from D. manni as previously described (15-17). Quercetin (18), quercitrin (19), amenthoflavone (20), and gedunine were obtained from Carapa grandifolia (21). Ascorbic acid was obtained from Hach Company, Loveland, CO, USA, while 1,1-diphenyl-2-picrylhydrazyl (DPPH) was purchased from Sigma, St. Louis, MO, USA.

\section{Antitrichomonal assay}

Trichomonas gallinarum was cultured in Ringer's-egg-serum medium according to the method of Boeck and Drbohlav (22) as modified by Levine (23). According to Meingasser and Thurner (24), the minimal lethal concentration (MLC) is the lowest concentration of the test extract or compound at which no motile organism is observed. Samples of the compounds (4-10 mg) were dissolved in $1 \mathrm{ml}$ dimethylsulfoxide and further diluted to appropriate final concentrations $(0.1,0.2$. $0.4,0.6,0.8,1,5,10,100,250,500,1000$ $\mu \mathrm{g} / \mathrm{ml})$ on 96 -well flat bottom microtiter plates held at $37^{\circ} \mathrm{C}$ in an incubator. At least three different concentrations were tested for each compound/extract in triplicate analyses. MLCs were determined by the microplate method (13). End points (defined as lack of motility) were assessed at 24 and $48 \mathrm{~h}$.

\section{Free radical scavenging activity}

The free radical scavenging activity of each extract and/or compound was analyzed by the DPPH assay (25) as described by Sanchez-Moreno et al. (26). The test compounds, at concentrations ranging from 10 to $100 \mu \mathrm{g} / \mathrm{ml}$, were mixed with $3 \mathrm{ml} 0.1 \mathrm{mmol}$ $\mathrm{DPPH} / 1$ (in ethanol) in a cuvette. The timecourse of the change in absorbance at 517 $\mathrm{nm}$ was monitored for $20 \mathrm{~min}$. The antioxi- 
dant activities of the extracts/compounds were evaluated by measuring the value of the absorbance at $517 \mathrm{~nm}$ when the reaction plateau step was reached. A minimum of three different concentrations for each compound/extract were tested in triplicate analyses. The percentage of remaining DPPH was calculated according to the equation:

$$
\% \mathrm{DPPH}_{\text {REM }}=[\mathrm{DPPH}]_{(\mathrm{t})} /[\mathrm{DPPH}]_{(\mathrm{o})} \times 100
$$

where $[\mathrm{DPPH}]_{(\mathrm{o})}$ is the remaining concentration of the stable radical without the antioxidant and $[\mathrm{DPPH}]_{(\mathrm{t})}$ is the remaining concentration at the reaction plateau step. For each compound/extract tested, a simple regression analysis was used to relate the response variable (percentage of remaining DPPH) to the independent variable (antioxidant concentration). The $\mathrm{EC}_{50}$ was interpolated or extrapolated from each related model. The $\mathrm{EC}_{50}$ values are expressed in terms of $\mu \mathrm{g}$ antioxidant per mg of DPPH.

\section{Results}

\section{Compounds isolated}

The twigs and the leaves yielded $60 \mathrm{~g}$ of extract each. Chromatographic separation of these extracts yielded $40 \mathrm{mg}$ isobavachalcone $(0.067 \%)$ from the twigs and $36 \mathrm{mg}$ $(0.06 \%)$ from the leaves; $29 \mathrm{mg}$ 4-hydroxylonchocarpin $(0.048 \%)$ from the twigs and 18 $\mathrm{mg}(0.03 \%)$ from the leaves; $35 \mathrm{mg}$ bartericin A $(0.058 \%)$ from the twigs and $46 \mathrm{mg}$ $(0.077 \%)$ from the leaves, while $30 \mathrm{mg}$ bartericin B (0.05\%) was obtained from the twigs but was not detected in the leaves.

\section{Antitrichomonal assays}

The MLCs for the extract of $D$. barteri leaves and twigs were found to be 15.625 and $15.625 \mu \mathrm{g} / \mathrm{ml}$, respectively. D. convexa leaf extract with an MLC of $125 \mu \mathrm{g} / \mathrm{ml}$ was found to be less potent than $D$. barteri ex- tract (Table 1). The activities of the compounds isolated from $D$. barteri, such as isobavachalcone, 4-hydroxylonchocarpin, bartericins $\mathrm{A}$ and $\mathrm{B}$, and stigmasterol, were compared with quercetin and quercitrin isolated from Mallotus oppositifolium, 6-prenylapigenin isolated from $D$. kameruniana and 6,8-diprenyleridictyol, dorsmanin $\mathrm{F}$ from $D$. manni; amenthoflavone from Cannarium shwuenfurthi, and gedunine from Carapa grandifolia (Table 2). The order of antitrichomonas activity of the compounds is: quercetin $(0.121 \mu \mathrm{g} / \mathrm{ml})>$ quercitrin $(0.244$ $\mu \mathrm{g} / \mathrm{ml}) \geq$ bartericin $\mathrm{B}(0.244 \mu \mathrm{g} / \mathrm{ml})>$ bartericin $\mathrm{A}(0.73 \mu \mathrm{g} / \mathrm{ml})>\operatorname{stigmasterol}(0.98$ $\mu \mathrm{g} / \mathrm{ml})>6,8$-diprenyleridictyol $=$ isobavachalcone $=$ dorsmanin $\mathrm{F}(31.25 \mu \mathrm{g} / \mathrm{ml})$. Some of these compounds were more effective than metronidazole $(0.625 \mu \mathrm{g} / \mathrm{ml})$. Quercetin, with an MLC of $0.121 \mu \mathrm{g} / \mathrm{ml}$ at $24 \mathrm{~h}$, is the most active compound.

\section{Antioxidant assays}

Figure 1 shows the relationship between the concentration of DPPH radicals and the time which elapsed since mixing the DPPH solution with the extracts and compounds examined. The lower the percent remaining $\mathrm{DPPH}$, the higher the antioxidant activity. The twig extract of $D$. barteri was more effective than the leaf extract. Four of the compounds and the twig extract displayed high antioxidant activities $\left(\mathrm{EC}_{50}<50 \mu \mathrm{g} / \mathrm{ml}\right)$.

\begin{tabular}{llrr} 
Table 1. Antitrichomonas activities of Dorstenia extracts. \\
\hline Product & Plant name & \multicolumn{2}{c}{ MLC $(\mu \mathrm{g} / \mathrm{ml})$} \\
\cline { 3 - 4 } & & $24 \mathrm{~h}$ & $48 \mathrm{~h}$ \\
\hline Leaves & D. convexa & $125 \pm 0$ & $125 \pm 0$ \\
Twigs & D. convexa & $437.5 \pm 125$ & $416 \pm 144$ \\
Leaves + twigs & D. barteri & $125 \pm 0$ & $125 \pm 0$ \\
Leaves & D. barteri & $15.625 \pm 0$ & $15.625 \pm 0$ \\
Twigs & D. barteri & $15.625 \pm 0$ & $15.625 \pm 0$
\end{tabular}

Data are reported as means \pm SD for assays in triplicate

$\mathrm{MLC}=$ minimum lethal concentration 
Table 2. Comparison of antitrichomonas activity of Dorstenia compounds with other active compounds.

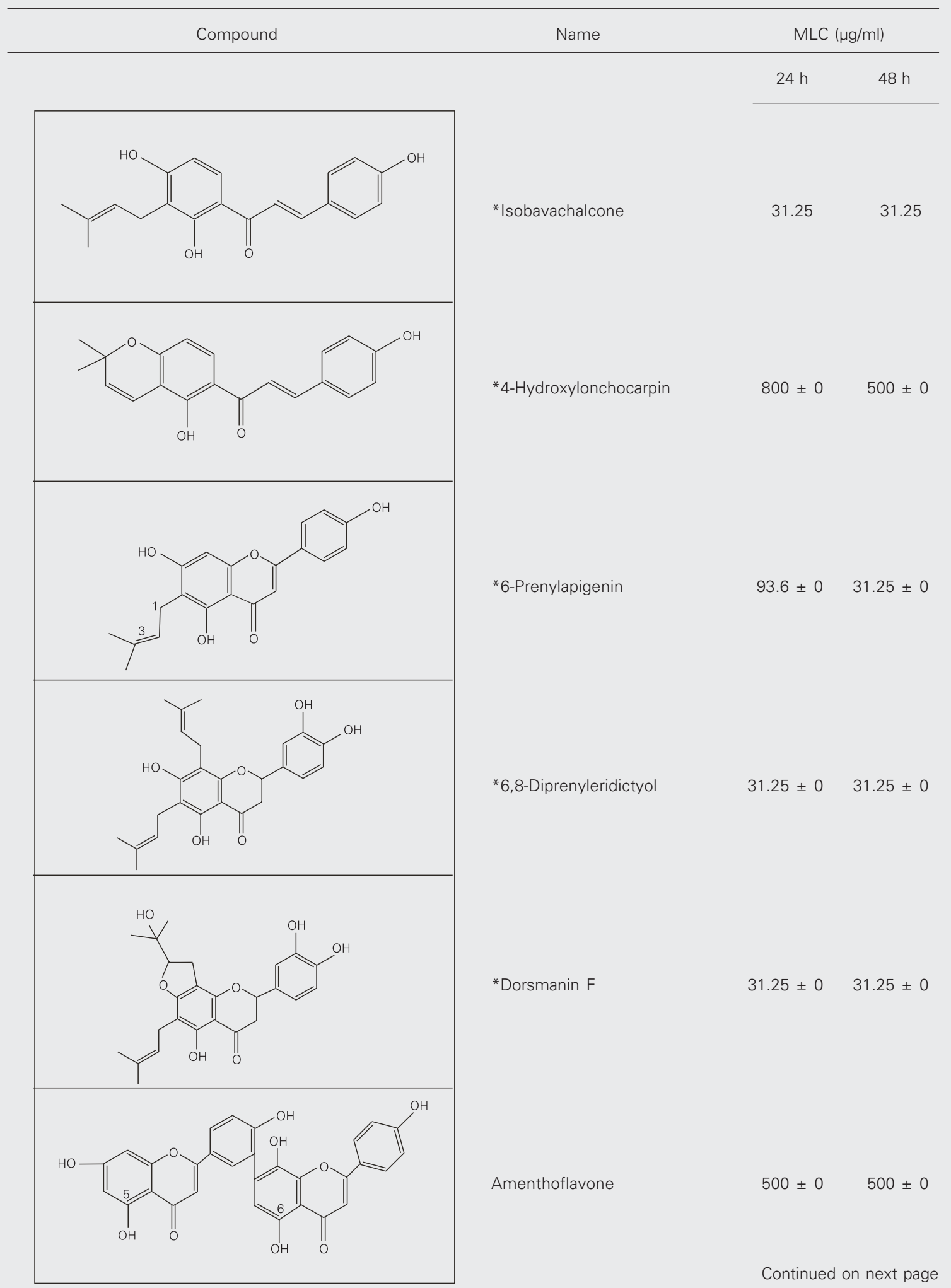




\section{Table 2 continued.}

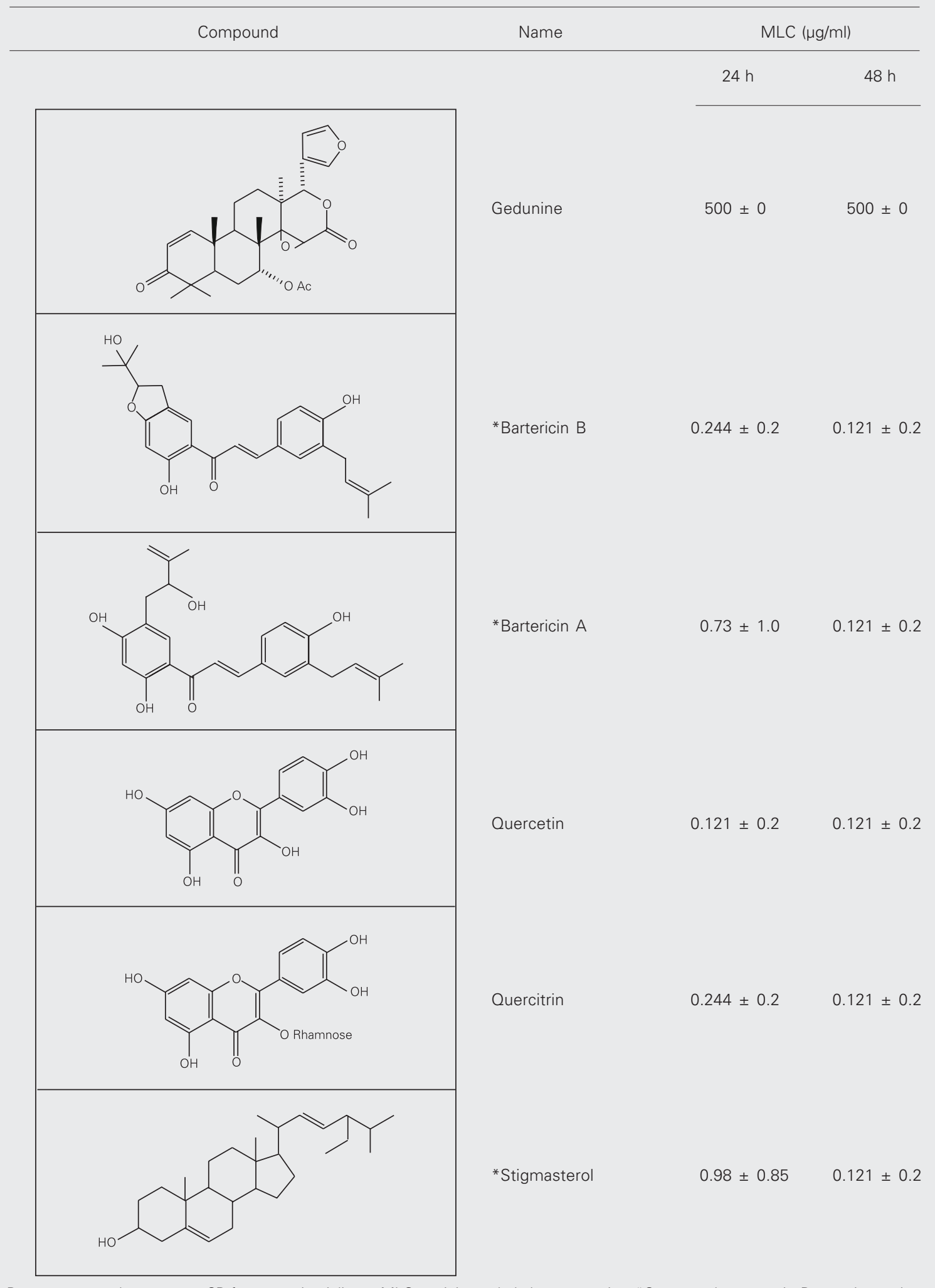

Data are reported as means \pm SD for assays in triplicate. $\mathrm{MLC}=$ minimum lethal concentration. ${ }^{*}$ Compounds present in Dorstenia species. 
These results are clearly shown in Table 3 . The effective median concentrations show that ascorbic acid has the highest activity. The order of potency of the compounds tested was: ascorbic acid $>$ quercitrin $>6,8$ diprenyleridictyol $>$ bartericin $\mathrm{A}>$ dorsmanin $\mathrm{F}>$ stigmasterol $>$ isobavachalcone $>6$ prenylapigenin.

\section{Discussion}

The observations that $T$. vaginalis is becoming resistant to metronidazole in about $5 \%$ of the population (12) coupled with the fact that metronidazole has unpleasant ad-
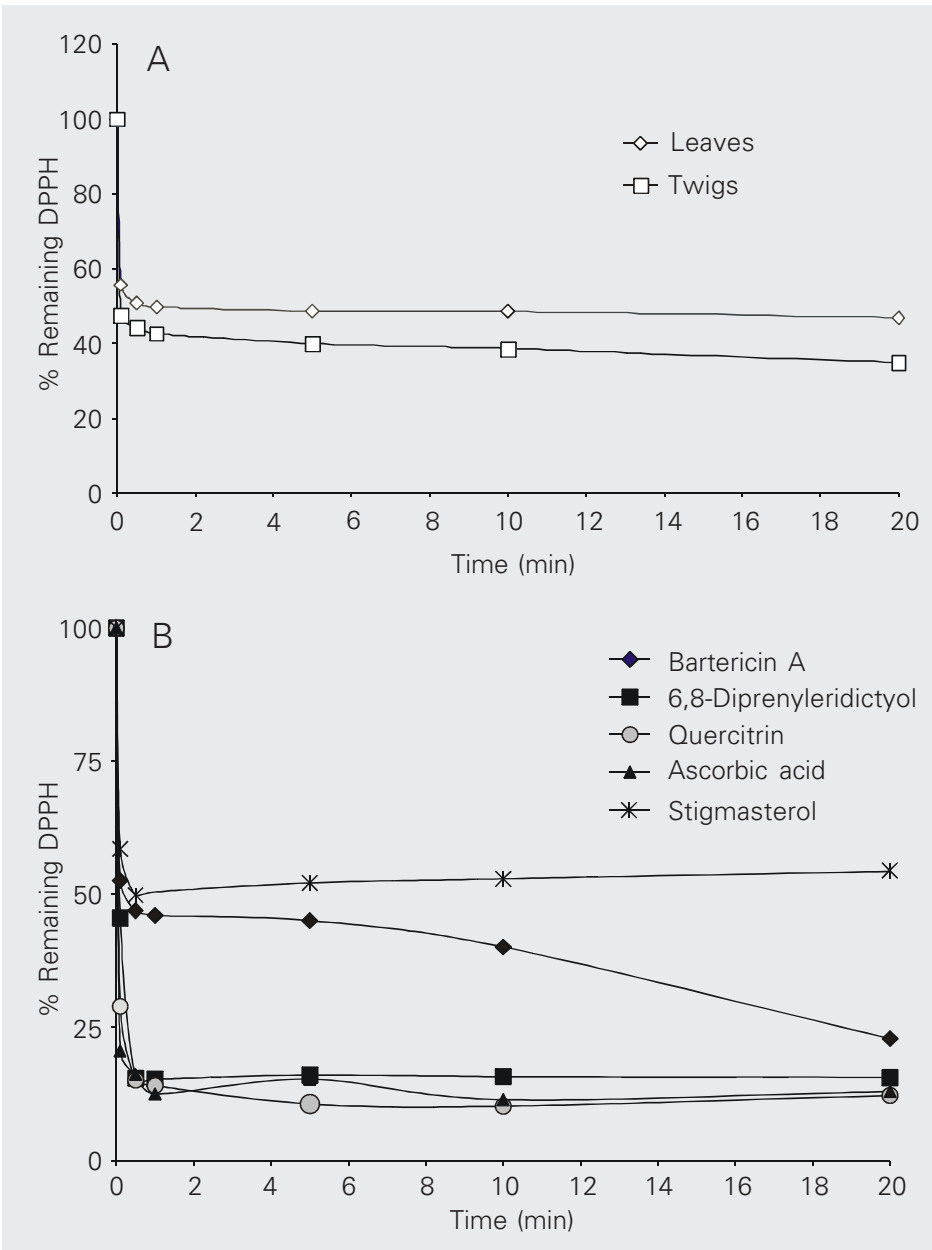

Figure 1. Upper panel, Antioxidant activities of Dorstenia barteri leaves and twigs (10-100 $\mu \mathrm{g} / \mathrm{ml})$. Lower panel, Antioxidant activities of selected compounds (10$100 \mu \mathrm{g} / \mathrm{ml}$ ). The percentage of remaining DPPH is an index of antioxidant activity equal to DPPH used at time (t) over the DPPH used at time zero. DPPH $=1,1$ diphenyl-2-picrylhydrazyl. verse effects (13) have led to search for phytochemicals in African medicinal plants with potential antitrichomonal activities. The results of the present study have shown that the extracts of $D$. barteri and $D$. convexa possess antitrichomonal activity. The active components (bartericins A and B and isobavachalcone) isolated from $D$. barteri were very active $(0.121-31.25 \mu \mathrm{g} / \mathrm{ml})$ against $T$. gallinarum. This fact may be responsible for the higher antitrichomonal activity of $D$. barteri than of $D$. convexa. The prenylated and geranylated chalcones were found to be as active as the prenylated flavones, 6-prenylapigenin and the diprenylated derivative 6,8-diprenyleridictyol. They were, however, about five times lower in activity than bartericins $\mathrm{A}$ and $\mathrm{B}$, quercetin and quercitrin.

Moderate antioxidant capacity $\left(\mathrm{EC}_{50}>50\right.$ $\mu \mathrm{g} / \mathrm{ml})$ and high antioxidant capacity $\left(\mathrm{EC}_{50}\right.$ $<50 \mu \mathrm{g} / \mathrm{ml}$ ) were found in the leaf and twig extracts of $D$. barteri and compounds tested (Table 3). The concentration needed to decrease the remaining DPPH by $50 \%$ (the initial substrate concentration $\mathrm{EC}_{50}$ ) is a parameter widely used to measure antioxidant power $(25,26)$. The lower the $\mathrm{EC}_{50}$, the higher the antioxidant power. The values found in our study are shown in Table 3 . According to Dufall et al. (27), the potency of the scaveng-

Table 3. Antioxidant activities of the products tested.

\begin{tabular}{ll}
\hline Extract/compound & $\mathrm{EC}_{50}(\mu \mathrm{g} / \mathrm{ml})$ \\
\hline Bartericin A & $47.85 \pm 2.15$ \\
6,8-Diprenyleridictyol & $32.12 \pm 1.10$ \\
Quercitrin & $28.16 \pm 0.84$ \\
Ascorbic acid & $19.33 \pm 0.3$ \\
D. barteri leaves & $60.46 \pm 1.55$ \\
D. barteri twigs & $48.12 \pm 2.97$ \\
Dorsmanin F & $53.89 \pm *$ \\
6-Prenylapigenin & $86.43 \pm 0.26$ \\
Isobavachalcone & $84.33 \pm 0.27$ \\
Leaves and twigs & $83.67 \pm 1.19$ \\
Stigmasterol & $62.18 \pm 0.64$
\end{tabular}

Data are reported as means \pm SD.

*Only one replicate was tested because the compound was not sufficient to run additional tests. 
ing activity of some compounds isolated from $D$. manni has the following range: dorsmanin $\mathrm{C}>6,8$-diprenyleridictyol $>$ dorsmanin $\mathrm{F}$. We also found that the order of potency was similar in our study: 6,8diprenyleridictyol $(32.12 \mu \mathrm{g} / \mathrm{ml})>$ dorsmanin $\mathrm{F}(53.89 \mu \mathrm{g} / \mathrm{ml})$. The order of potency was as follows: ascorbic acid $>$ quercitrin $>6,8$ diprenyleridictyol $>$ bartericin $\mathrm{A}>$ dorsmanin $\mathrm{F}>$ stigmasterol $>$ isobavachalcone $>6$ prenylapigenin. The higher antioxidant property exhibited by the $D$. barteri twig extract than the leaf extract may be due to the relative presence or distribution of active components in the extracts.

One third of the World's cancer cases are caused by chronic infections (28). In Asia and Africa, hepatitis $\mathrm{B}$ and $\mathrm{C}$ viruses infect about 500 million people and are a major cause of hepatocellular carcinoma (29). Schistosomiasis is another major chronic infection which is widespread in Africa and China. The African schistosomal worm lays eggs in the colon, producing inflammation that often leads to colon cancer (30). There is evidence that this disease may be on the increase in the southwestern part of Nigeria $(31,32)$. The common link between oxidants and inflammatory reactions, infection and other disorders has been well established $(33,34)$. In chronic infection and inflammation, release of leukocytes and other phagocytic cells readily defends the organism from further injury. The cells do this by releasing free oxidant radicals, $\mathrm{NO}, \mathrm{O}_{2}^{-}, \mathrm{H}_{2} \mathrm{O}_{2}$, and $\mathrm{OH}^{-}$, as powerful oxidant mixtures $(28,33)$. Antioxidants appear to inhibit the actions of some of the oxidants generated in inflammation (28). No wonder, therefore, that the extracts of $D$. barteri exhibited both antitrichomonal and antioxidant properties in this study. The antioxidant properties of these chemical constituents of $D$. barteri extracts could be used to explain, at least in part, the anti-inflammatory and antinociceptive activities obtained in our earlier study (35).

Endogenous enzymatic antioxidants offer protective defenses in the body (28) to limit the levels of reactive oxidants and the damage they inflict. In addition, consumption of dietary antioxidants appears to be associated with a lowered risk of degenerative diseases. Prenylated flavonoids have been shown to influence cyclooxygenase and lipoxygenase activity $(36,37)$ and to inhibit platelet aggregation (38). The former action may account for the anti-inflammatory and antitrichomonas action of plants containing such compounds. The antioxidant activity shown by the extracts and compounds tested in this study may lend credence to the use of Dorstenia species as anti-infective agents in folk medicine.

The prenylated flavonoids and the isolated compounds with antioxidant properties reported here probably account for the antioxidant and antitrichomonal actions of these extracts.

\section{Acknowledgments}

Thanks are extended to Prof. A. Afolayan of the Department of Biochemistry for spectrometry facilities.

\section{References}

1. Mabberley DJ (1987). The Plant Book. Cambridge University Press, Cambridge, UK

2. Bouquet A (1969). Feticheurs et Medecines Traditionnelles du Congo Brazaville. Memoires ORSTOM, 36: 295.

3. Abegaz BM \& Ngadjui BT (1999). Chemistry of marketed plants of eastern and southern Africa Nigeria. Journal of Natural Products and Medicine, 3: 19-25.

4. Buvé $A$, Weiss HA, Laga $M$ et al. (2001). The epidemiology of trichomoniasis in women in four African cities. AIDS, 15 (Suppl 4): S89-S96.

5. Anosike JC, Onwuliri CO, Inyang RE, Akoh JI, Nwoke BE, Adeiyongo CM, Okoye SN \& Akogun OB (1993). Trichomoniasis 
amongst students of a higher institution in Nigeria. Applied Parasitology, 34: 19-25.

6. Bakare RA, Ashiru JO, Adeyemi-Doro FA, Ekweozor CC, Oni AA, Okesola AO \& Adebayo JA (1999). Non-gonococcal urethritis (NGU) due to trichomonas vaginalis in Ibadan. West African Journal of Medicine, 18: 64-68.

7. Nimorsi OP, Egwunyenga AO \& Bajomo DO (2001). Survey of urinary schistosomiasis and trichomoniasis in a rural community in Edo State, Nigeria. Journal of Communicable Diseases, 33: 96-101.

8. Ogbonna Cl, Ogbonna IB, Ogbonna AA \& Anosike JC (1991). Studies on the incidence of Trichomonas vaginalis amongst pregnant women in Jos area of Plateau State, Nigeria. Angewandte Parasitologie, 32: 198-204.

9. Obunge OK, Brabin L, Dollimore N, Kemp J, Ikokwu-Wonodi C, Babatunde S, White S, Briggs ND \& Hart CA (2001). A flowchart for managing sexually transmitted infections among Nigerian adolescent females. Bulletin of the World Health Organization, 79: 301305.

10. Wang SY \& Jiao H (2000). Scavenging capacity of berry crops on superoxide radicals, hydrogen peroxide, hydroxyl radicals, and singlet oxygen. Journal of Agriculture and Food Chemistry, 48: 56775688.

11. Sies H (1991). Oxidative Stress; Oxidants and Antioxidants. Academic Press, Orlando, FL, USA.

12. Lossick JG (1989). Therapy of urinogenital trichomoniasis. In: Honigberg BM (Editor), Trichomonads Parasitic in Man. Springer Verlag, New York, 324-341.

13. Narcisi EM \& Secor NE (1996). In vitro effect of tinidazole and furazolidone on metronidazole-resistant Trichomonas vaginalis. Antimicrobial Agents and Chemotherapy, 40: 1121-1126.

14. Ngameni B, Ngadjui BT, Folefoc GN, Watchueng J \& Abegaz BM (2004). Diprenylated chalcones and other constituents from the twigs of Dorstenia barteri Var. Subtriangularis. Phytochemistry, 65: 427-432.

15. Ngadjui BT, Abegaz BM, Dongo E, Tamboue H \& Fogue K (1998). Geranylated and prenylated flavonoids from the twigs of Dorstenia mannii. Phytochemistry, 48: 349-354.

16. Ngadjui BT, Dongo E, Tamboue H, Fogue K \& Abegaz BM (1999). Prenylated flavanones from the twigs of Dorstenia mannii. Phytochemistry, 50: 1401-1406.

17. Ngadjui BT, Kouam SF, Dongo E, Kapcha GW \& Abegaz BM (2000). Prenylated flavonoids from the aerial parts of Dorstenia mannii. Phytochemistry, 55: 915-919.

18. Subramanian SS \& Nair AGR (1971). Polyphenols of Lannea coromandelica. Phytochemistry, 10: 1939-1940.

19. Wagner H, Horhammer L \& Kiraly IC (1970). Flavon-C-glykoside in Croton zambezicus. Phytochemistry, 9: 897-899.

20. Tamboue H, Fotso S, Ngadjui BT, Dongo E \& Abegaz BM (2000). Phenolic metabolites from the seeds of Canarium schweinfurthii. Bulletin of the Chemical Society of Ethiopia, 14: 155-160.

21. Ayafor JF, Kimbu SF, Ngadjui BT, Akam TM, Dongo E, Sondengam BL, Connolly JD \& Rycroft DS (1994). Limonoids from Carapa grandiflora (Meliaceae). Tetrahedron, 50: 9343-9354.

22. Boeck WC \& Drbohlav J (1925). Laboratory culture of protozoal parasites. Proceedings of the National Academy of Sciences, USA, 11: $235-238$

23. Levine ND (1961). Laboratory diagnosis of protozoan infections. In:
Levine ND (Editor), Protozoan Parasites of Domestic Animals and Man. Burgess Publishing Company, Minneapolis, MN, USA, 377393.

24. Meingasser JG \& Thurner J (1979). Strain of Trichomonas vaginalis resistant to metronidazole and other 5-nitroimidazoles. Antimicrobial Agents and Chemotherapy, 15: 254-257.

25. Brand-Williams W, Cuvelier ME \& Berset C (1995). Use of a free radical method to evaluate antioxidant activity. LebensmittelWissenschaft and Technologie, 28: 25-30.

26. Sanchez-Moreno C, Larrauri JA \& Saura-Calixto F (1998). A procedure to measure the antiradical efficiency of polyphenols. Journal of the Science of Food and Agriculture, 76: 270-276.

27. Dufall KG, Ngadjui BT, Saimeon KF, Abegaz BM \& Croft KD (2003) Antioxidant activity of prenylated flavonoids from the West African medicinal plant Dorstenia manni. Journal of Ethnopharmacology, 87: $67-72$

28. Ames BN, Shigenaga MK \& Hagen TM (1993). Oxidants, antioxidants and the degenerative diseases of aging. Proceedings of the National Academy of Sciences, USA, 90: 7915-7922

29. Chen MG (1988). Progress in assessment of morbidity due to $S$. haematobium infection: A review. Tropical Diseases Bulletin, 85: 256.

30. Chen MG \& Mott KE (1989). Progress in assessment of morbidity due to schistosomiasis; review of the recent literature. Tropical Diseases Bulletin, 86: 1-56.

31. Adewunmi CO, Furu $P$, Christensen NO, Marquis BB \& Fagbola M (1990). Endemicity and seasonality of transmission of human schistosomiasis in Ile-Ife, Southwest Nigeria. Tropical Medicine and Parasitology, 41: 443-444.

32. Adewunmi CO, Gebremedhin G, Becker W, Olorunmola FO, Dorfler G \& Adewunmi TA (1993). Schistosomiasis and intestinal parasites in rural villages in southwest Nigeria: An indication for expanded programme on drug distribution and integrated control programme in Nigeria. Tropical Medicine and Parasitology, 44: 177-180.

33. Mongelli E, Desmarchelier C, Rodriguez-Talou J, Coussio J \& Ciccia $\mathrm{G}$ (1997). In vitro antioxidant and cytotoxic activity of extracts of Baccharis coridifolia DC. Journal of Ethnopharmacology, 58: 157163.

34. Wang $H$, Nair MG, Strasburg GM, Chen-Chang Y, Booren AM, Gray IJ \& DeWitt DL (1999). Antioxidant and anti-inflammatory activities of anthocyanins and their aglycone, cyaniding from Tart Cherries. Journal of Natural Products, 62: 294-296.

35. Omisore NOA, Adewunmi CO, Iwalewa EO, Ngadjui BT, Watchueng J, Abegaz BM \& Ojewole JAO (2004). Antinociceptive and antiinflammatory effects of Dorstenia barteri (Moraceae) leaf and twig extracts in mice. Journal of Ethnopharmacology, 95: 7-12.

36. Kimura U, Okuda H, Homura T, Fukai T \& Arichi S (1986). Effects of phenolic constituents from the mulberry tree on arachidonate metabolism in rat platelets. Journal of Natural Products, 49: 639-644.

37. Chi TS, Jong HG, Son KH, Chang HW \& Kim HP (2001). Effects of naturally occurring prenylated flavonoids on enzymes metabolising arachidonic acid: Cyclooxygenase and lipoxygenase. Biochemical Pharmacology, 62: 1185-1191.

38. Ko HH, Wang JJ, Lin HC, Wang JP \& Lin CN (1999). Chemistry and biological activities of constituents from Monus australis. Biochimica et Biophysica Acta, 1428: 293-299. 